\title{
Protective effect of Silymarin against kidney injury induced by carbon tetrachloride in male rats
}

\author{
M.A. Ahmed", H.M. Tayawi and M.K. Ibrahim \\ Department of Biology, College of Education for Pure Science, Tikrit university, Tikrit, Iraq \\ "email: measer80@gmail.com
}

(Received May 18, 2018; Accepted June 26, 2018)

\begin{abstract}
The herbal drugs have a protective effect for kidney function against chemical toxicity. 24 male rats divided into 4 groups and treated as following, control group administrated orally with $1 \mathrm{ml} / \mathrm{kg}$. B.W physiological solution (0.9\%), One dose Carbon Tetrachloride $\left(\mathrm{CCl}_{4}\right) 3 \mathrm{ml} / \mathrm{kg}$. B.W, Silymarin $150 \mathrm{mg} / \mathrm{kg}$. B.W and Silymarin $150 \mathrm{mg} / \mathrm{kg}$. B.W with $\mathrm{CCl}_{4} 3 \mathrm{ml} / \mathrm{kg}$. B.W for 30 days. Oxidative stress resulted by $\mathrm{CCl}_{4}$ caused increasing in Creatinine, Urea, total protein, Albumin, malondialdehyde (MDA) levels decreasing in Glutathione (GSH) and superoxide dismutase (SOD) levels in serum and congestion, degeneration and desquamation in kidney tissue. We concluded that Silymarin showed protective effect via increasing GSH, decreasing creatinine, Urea, total protein and MDA levels in serum and protect kidney tissue in rats.
\end{abstract}

Keywords: Silymarin, $\mathrm{CCl}_{4}$, Kidney toxicity, Antioxidant Available online at http://www.vetmedmosul.com

$$
\begin{aligned}
& \text { التأثير الوقائي للسلمارين ضد اصابة الكلى الناجم عن رباعي كلوريد الكربون في ذكور الجرذان } \\
& \text { ميسر عبدالله احم، حسين محمد طياوي و تحمد خليل إبراهيم } \\
& \text { قسم علوم الحياة، كلية التربية للعلوم الصرفة، جامعة تكريت، تكريت، العراق }
\end{aligned}
$$

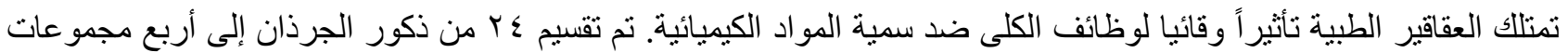

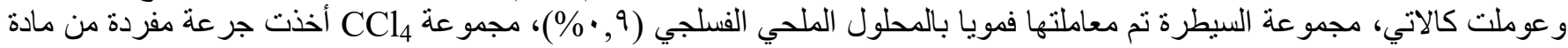

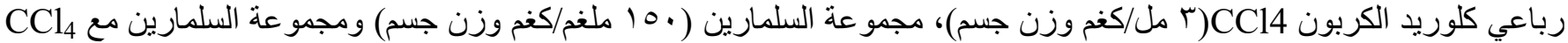
ولمدة ثلاثين يوما. الجها التاكسدي الناجم عن

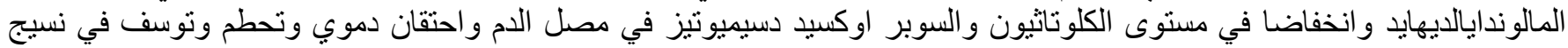

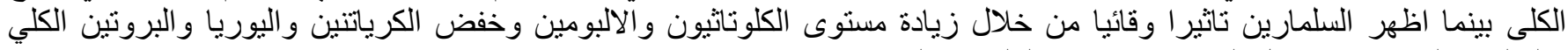
والمالوندايالديهايد في مصل الدم وحماية نسيج الكلى في الجرذانيان.

\section{Introduction}

Kidney is a vital organ to achieve homeostasis and has important biological function in regulation of extracellular fluid volume, acid-base balance, electrolytes and excretion of metabolic wastes (1). Kidney is very sensitive to xenobiotic $(2,3)$. Xenobiotic such as chemotherapeutic materials and bacteria, viruses' metabolites usually produce reactive oxygen species ROS and or reactive nitrogen species RNS during xenobiotic metabolism $(4,5)$. ROS and RNS have been demonstrated cause cell intoxication when they generate in excessive amount or depletion of antioxidant defense systems which cause lipid peroxidation and oxidative stress $(6,7)$. Carbone tetrachloride $\left(\mathrm{CCl}_{4}\right)$ intoxication chemical compound has been used as experimental model to induce stress mimics 
pathophysiological status in vivo (8). $\mathrm{CCl}_{4}$ generate free radicals in tissue in addition $\mathrm{CCl}_{4}$ toxicity represented in formation of carbon trichloride $\left(\mathrm{CCl}_{3}\right)$ which interact with oxygen to form $\mathrm{CCl}_{3} \mathrm{O}_{2}$ (8). Herbal drugs used in widespread around the world because their activity against many diseases and intoxication (9). Silymarin is a compound derived from Silybum marianum is an ancient medicinal plant the common name is milk thistle. silymarin is the active compound which containing four flavonolignan isomers: silybin, isosilybin, silydianin and silychristin. silybin is the most active compound (9-11). Silymarin and one of its component silybin are available now as capsules and tablets under trade names such as legalon, livergol and silipide (9). Silymarin is a safe herbal compound soon it used according to the physiological recommended doses $(12,13)$ it has been used as antifibrotic, antioxidant, anti-inflammatory and against hepatotoxicity. $(12,14,15)$. The mechanism of silymarin action is still poorly understood (16). Data from literatures indicated that silymarin act as antioxidant, free radical scavengers, regulator of intracellular glutathione GSH and stabilizing cell membrane (17-19). This study aimed to detect the biological vitality of silymarin in protecting kidney tissue against oxidative stress induced by $\mathrm{CCl}_{4}$ toxicity.

\section{Materials and methods}

\section{Experimental design}

Twenty-four adult male rats weighted 200-250 g housed at the animal units in faculty of veterinary / Tikrit university. Animals were free access to standard rat food, water and standard environmental conditions in the animal house unit. during the experimental period that continued for 30 days. Rats divided equally into four groups first is control group treated orally with physiological solution $(0.9 \%)$ while the other three groups treated orally with single dose of $\mathrm{CCl} 4(3 \mathrm{ml} / \mathrm{kg})$ added to equivalent volume of Olive oil, orally dose of silymarin $(150 \mathrm{mg} / \mathrm{kg})$ (19) and silymarin $(150 \mathrm{mg} / \mathrm{kg})$ with $\mathrm{CCl}_{4}(3 \mathrm{ml} / \mathrm{kg})$ respectively. Silymarin were supplied from Signova Pharma Pvt Ltd company.

\section{Serum preparation}

Rats anesthetized and sacrificed, blood samples were taken through cutting the Jugular vein. The blood serum collected using centrifuge (3000 rpm for $15 \mathrm{~min}$ ) and kept at $-20{ }^{\circ} \mathrm{C}$. To speculate renal function of experimental animals treated by $\mathrm{CCl}_{4}$ and silymarin.

\section{Biochemical analysis}

Urea, Creatinine, total protein and Albumine levels in serum were measured, and also to clarify the association of renal function and oxidative stress, MDA, GSH and SOD were measured. All serum analyzing used by spectrophotometer and analysis kits materials and methods that obtained from supplier company BIOLABO SAS (20).

\section{Histological study}

Kidney tissue were obtained to evaluate whether $\mathrm{CCl}_{4}$ and silymarin elicit alteration in the kidney tissue. Tissue immediately fixed in $10 \%$ formalin for 24 hours then washed via water and dehydrated by gradient series concentration of alcohol, embedded in paraffin and slices of $5 \mu \mathrm{m}$ thickness by microtome, sections stained with Hematoxylin and Eosin (HE) (21). Slides were observed using light microscopy for diagnosis the kidney histology and morphology.

\section{Statistical Analysis}

Data analyzed using one-way analysis of variance (oneway ANOVA) independent samples test. Differences between groups determined by Duncan multiple range test. The value $\mathrm{P}<0.01$ regarded as statistically significant value (22).

\section{Results}

Serum analyzing results (Table 1 and 2) demonstrated the effect of CCl4 to increase levels of creatinine, urea, MDA and decreasing in total protein, albumin, GSH and SOD in compare to control group. Silymarin group showed significant decrease in creatinine, urea and MDA and significant increase in albumin and GSH but no differences noticed in total protein, albumin and SOD in compare to control group. While treatment by $\mathrm{CCl}_{4}$ with silymarin showed decreasing in creatinine, Urea, MDA levels and increasing in Total protein, albumin and GSH in compare to $\mathrm{CCl}_{4}$ group, but no difference in SOD level. Kidney tissue demonstrated the damage effect of $\mathrm{CCl}_{4}$ represented in degeneration in glomerular, tubular and interstitial tissue, desquamation, necrosis in some cells and congestion. (Figure 1-B) in compare to control group (Figure 1-A). While silymarin showed decreasing in degeneration, desquamation and congestion (Figure 1C, 1D) in compare to $\mathrm{CCl}_{4}$ group (Figure 1-B). Creatinine and Urea are metabolites usually used for determination of glomerular filtration rate and then renal function (23). $\mathrm{CCl}_{4}$ caused an impairment to clear the blood from these metabolites into the urine through damages in kidney tissue studies reported that $\mathrm{CCl} 4$ Initiated lipid peroxidation, reduces renal (GSH/GSSG) ratio in kidney cortex, microsomes and mitochondria $(24,25)$ which reflect the high plasma levels of creatinine and urea (Table 1, Figure1-B), this diagnostic as impaired renal function occurred as a result to renal injury in rats $(26,27)$. Rats administrated with $\mathrm{CCl}_{4}$ showed high oxidative stress (Table 1) and damages in kidney tissue (Figure 1-B). 
Table 1: Assesment of kidney function through levels of some biochemical parameters

\begin{tabular}{lcccc}
\hline \multirow{2}{*}{ Parameters } & \multicolumn{3}{c}{ Groups } \\
\cline { 2 - 5 } & Control & CCL4 $(3 \mathrm{ml} / \mathrm{kg}$. B.W $)$ & Silymarin $(150 \mathrm{mg} / \mathrm{kg} . \mathrm{B} . \mathrm{w})$ & $\mathrm{CCL}_{4}+$ Silymarin \\
\hline Creatinine $(\mathrm{mg} / \mathrm{dl})$ & $0.8333 \pm 0.081^{\mathrm{b}}$ & $1.1333 \pm 0.136^{\mathrm{a}}$ & $0.7 \pm 0.089^{\mathrm{b}}$ & $0.85 \pm 0.447^{\mathrm{b}}$ \\
Urea $(\mathrm{mg} / \mathrm{dl})$ & $40.916 \pm 1.696^{\mathrm{c}}$ & $51.266 \pm 1.291^{\mathrm{a}}$ & $38.75 \pm 0.967^{\mathrm{c}}$ & $46.433 \pm 0.852^{\mathrm{b}}$ \\
Total protein $(\mathrm{g} / \mathrm{dl})$ & $7.266 \pm 0.175^{\mathrm{b}}$ & $5.8 \pm 0.368^{\mathrm{d}}$ & $6.65 \pm 0.339^{\mathrm{c}}$ & $8 \pm 0.303^{\mathrm{a}}$ \\
Albumin $(\mathrm{g} / \mathrm{dl})$ & $4.316 \pm 0.306^{\mathrm{a}}$ & $3.55 \pm 0.251^{\mathrm{b}}$ & $4.65 \pm 0.327^{\mathrm{a}}$ & $4.533 \pm 0.250^{\mathrm{a}}$ \\
\hline
\end{tabular}

Values expressed means $( \pm$ SEM) of 6 rats. Different letters mean significant difference at $\mathrm{P}<0.01$.

Table 2: Changes in oxidant- antioxidant levels in experimental groups

\begin{tabular}{lcccc}
\hline \multirow{2}{*}{ Parameters } & \multicolumn{3}{c}{ Groups } \\
\cline { 2 - 5 } & Control & CCL4 $(3 \mathrm{ml} / \mathrm{kg} . \mathrm{B} . \mathrm{W})$ & Silymarin $(150 \mathrm{mg} / \mathrm{kg} . \mathrm{B} . \mathrm{w})$ & CCL $_{4}+$ Silymarin \\
\hline Glutathione $(\mu \mathrm{mol} / \mathrm{L})$ & $4.098 \pm 0.442^{\mathrm{a}, \mathrm{b}}$ & $2.235 \pm 0.326^{\mathrm{c}}$ & $4.633 \pm 0.338^{\mathrm{a}}$ & $3.616 \pm 0.231^{\mathrm{b}}$ \\
Superoxide dismutase $(\mu \mathrm{mol} / \mathrm{L})$ & $1.183 \pm 0.124^{\mathrm{a}}$ & $0.953 \pm 0.029^{\mathrm{b}}$ & $0.988 \pm 0.162^{\mathrm{a}, \mathrm{b}}$ & $0.973 \pm 0.129^{\mathrm{b}}$ \\
Malondialdehyde $(\mu \mathrm{mol} / \mathrm{L})$ & $1.966 \pm 0.196^{\mathrm{c}}$ & $4.2 \pm 0.296^{\mathrm{a}}$ & $1.58 \pm 0.263^{\mathrm{c}}$ & $2.771 \pm 0.607^{\mathrm{b}}$ \\
\hline
\end{tabular}

Values expressed means ( \pm SEM) of 6 rats. Different letters mean significant difference at $\mathrm{P}<0.01$.

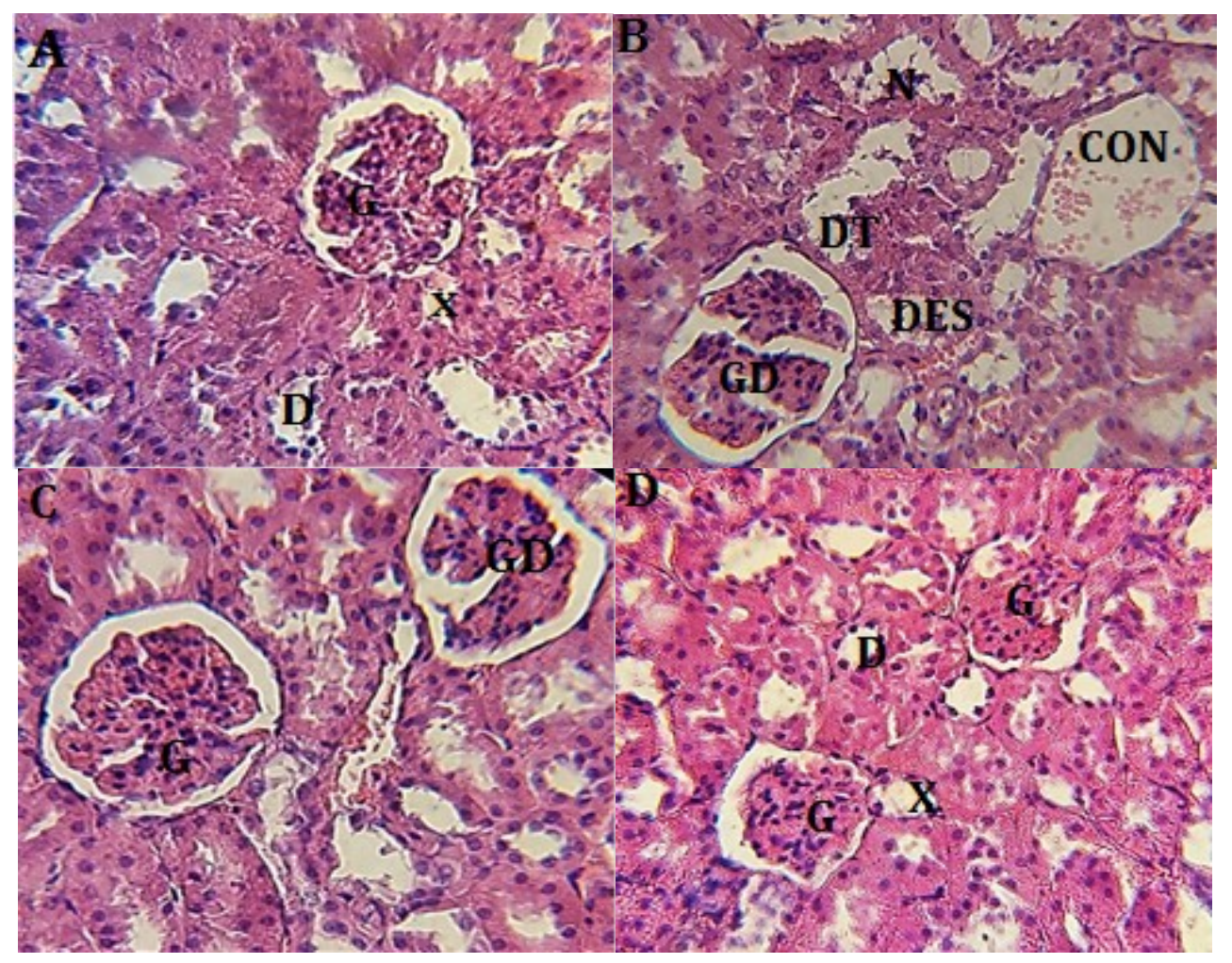

Figure 1: A. Control group showing normal kidney tissue glomeruli (G), proximal (X) and distal tubular (D). B. Damage in kidney tissue resulted via $\mathrm{CCl}_{4}$, glomerular degeneration (GD), degeneration in renal tubular (DT), interstitial tissue, desquamation of some cells (DES), congestion (CON) and moderate to severe necrosis (N). C and D Show effectiveness of Silymarin in attenuated $\mathrm{CCl}_{4}$ effect in compare to $\mathrm{CCl}_{4}$ group. (H\&E, 40x).

\section{Discussion}

The metabolic conversion of $\mathrm{CCl}_{4}$ by cytochrome $\mathrm{p}-450$ generates reactive free radicals that initiate cell necrosis, lipid peroxidation, elevate MDA levels, depletion in GSH levels and impair antioxidants activity (28) which affect negatively renal function by exhibit renal vasoconstriction 
or inhibit the glomerular filtration coefficient; and decreasing filtration rate (25).

Silymarin has an antioxidant, free radical scavengers, intracellular glutathione GSH regulator and stabilizing cell membrane activity. Pathological changes in kidney tissue has been demonstrated when rats exposed to $\mathrm{CCl}_{4}$. Animals have unique system for protecting against ROS (29). Rats can resist the elevating in ROS using SOD and GSH. GSH is essential non-enzymatic antioxidant associated with glutathione transferase in attenuated and scavenging free radicals (30) SOD is an enzymatic antioxidants dismutation superoxide to nontoxic molecules (31). In this study Silymarin demonstrated the ability to prevent $\mathrm{CCl}_{4}$ from lipid peroxidation in kidney tissue and has a cytoprotection activities, also elevated ROS scavengers such as SOD and $\mathrm{GSH}$, and reduced lipid peroxidation which indicated by MDA level. Studies reported $(9,26)$ that silymarin increase gene expression of antioxidant enzymes. Oxidative stress inhibits insulin secretion which making cell to depend on proteins and fats oxidation as an energy source and that cause elevating in urea and creatinine levels. Silymarin has ability to recover pancreatic function to secrete insulin (32). These findings demonstrated that silymarin has a protective role against $\mathrm{CCl}_{4}$ induced kidney injury by lipid peroxidation.

\section{References}

1. Schnellmann, RG. Toxic responses of the kidney. In: Claassen CD. Editor. Cassarett and Doull's Toxicology. The Basic Science of Poisons, $7^{\text {th }}$ ed. New York (NY): McGraw-Hill Medical Publishing Division; 2008. p. 583-608.

2. Jaramillo F, Rincón AR, Rico R. Fundamentos de la Toxicología Ambiental. Toxicología Ambiental, first ed. Textos Universitarios, UAA y UdG, Aguascaleintes, Ags, México,2006. pp. 15-31.

3. Jaramillo F, Rodríguez M, Reyes J. Toxicología renal. Toxicología Básica.Textos Universitarios UAA y UdG, Aguascaleintes, Ags México. 2009;1:137-166.

4. Jacobs AT. Marnett, L.J. Systems analysis of protein modification and cellular responses induced by electrophile stress. Acc Chem Res. 2010;43:673-683.

5. Sun B and Karin M. Nf-Kappab signaling, liver disease and hepatoprotective agents. Oncogene. 2008;1(27):6228-6244.

6. Avery SV. Molecular targets of oxidative stress. Biochem J 2011;434:201-210.

7. D'Ischia M, Napolitano A, Manini P, Panzella L. Secondary targets of nitrite derived reactive nitrogen species: nitrosation/nitration pathways, antioxidant defense mechanisms and toxicological implications. Chem Res Toxicol. 2011;24:2071-2092.

8. Ganie S, Haq E, Hamid A, Qurishi Y, Mahmood Z, Zarqar B, Masood A, Zarqar M. Carbon tetrachloride induced kidney and lung tissue damages and antioxidant activities of the aqueous rhizome extract of Podophyllum hexandrum. BMC Comp Alter Med. 2011;11:17.

9. Dermarderosin A. The review of natural products. $1^{\text {st }}$ ed. United States of America: Facts and Comparisons; 2001.

10. Kaur $M$ and Agarwal R. Silymarin and epithelial cancer chemoprevention: How close we are to bedside? Toxicol Appl Pharm. 2007;224:350-359.

11. Basiglio CL, Sanchez Pozzi EJ, Mottino AD, Roma MG. Differential effects of silymarin and its active component silybinin on plasma membrane stability and hepatocellular lysis. Chem Biol Interact. 2009;179:297-303.

12. Wen WJ, Lin L, Tsai T. Drug-drug interactions of silymarin on the perspective of pharmacokinetics. J Ethno Pharmacol. 2009;121:185193.

13. Toklu HZ, Tunali AT, Erkanli G, Yuksel M, Ercan F, Sener G. Silymarin, the antioxidant component of silybum marianum, protects against burn-induced oxidative skin injury. Burns. 2007;33:908-916.

14. Cesanow N, Fleminh H, Kelly GA. PDR for nonprescription drugs, dietary supplements, and herbs. $27^{\text {th }}$ ed. Montvale: Thomson PDR; 2006.

15. Karimi G, Ramezani M, Tahoonian Z. Cisplatin nephrotoxicity and protection by milk thistle extract in rats. Evid Based Complement Alternat Med. 2005;2:383-386.

16. Fraschini F, Demartini G, Esposti D. Pharmacology of Silymarin,Clin. Drug Invest. 2002;22(1):1.

17. Adejo GO, Gnimintakpa JM, Olowoniyi OD and Matthew PO. Andrographis peniculata: Capabilities against Free Radicals, Lipid Peroxidation, Hepatotoxicity, and Nephrotoxicity. Ope Acc Lib J. 2016;3:e2541.

18. Ahmed M, Hamid A, Tayawi M. Silymarin effect as an antioxidant to improve damages induced by $\mathrm{CCl} 4$ on some characteristics of male rats reproductive system. Tikrit J Pure Sci. 2018;23(2):60-65.

19. Aljubori A, Rahim S. The protective effect of aqueous and alcoholic extracts of Alhagi maurorum plant against experimentally created live damage in male rats using $\mathrm{CCl}_{4}$ [master's thesis]. Tikrit: University of Tikrit; 2015. $132 \mathrm{p}$.

20. Tietz NW. Clinical guide to laboratory test. 2006. $4^{\text {th }}$ ed. p. 10961099.

21. Bancroft J, Cook H. Manual of histological techniques. London: Churchill Livingstone; 1998.

22. Mohammed NT, Al-Rawi KM, Younis MA, Al-Morani WK. Principles of Statistics. Mosul: Book House for Printing and Publishing; 1986

23. Iseghohi SO, Orhue EJ. Aqueous extract of Dennettia tripetala (Pepperfruit) protects the liver and kidney against carbon tetrachloride-induced damage in rats. NISEB Journal. 2015;15(3):1.

24. Adewole SO, Salako AA, Doherty OW, Naicker T. Effect of melatonin on carbon tetrachloride induced kidney injury in wistar rats. Afr J Biomed Res. 2007;10:153-164.

25. Adewole S, Salako A, Doherty O. and Naicker T. Effect of melatonin on carbon tetrachloride- induced kidney injury in wistar rats. Afr J Biomed Res. 2007;10:153-164.

26. Venkatanarayana G, Sudhakara G, Sivajyothi P, Indira P. Protective effects of curcumin and vitamin E on carbon tetrachloride-induced nephrotoxicity in rats. Excli. 2012;11:641-650.

27. Liu W, Du Y, Liu J, Wang H, Sun D, Liang D, Zhao L. and Shang J. Effects of atrazine on the oxidative damage of kidney in Wister rats. Int J Clin Exp Med. 2014; 7(10):3235-3243.

28. Li X, Zheng Q, Wang Y, Zhang HX. Theoretical insights into the reductive metabolism of $\mathrm{CCl}_{4}$ by cytochrome $\mathrm{P} 450$ enzymes and the $\mathrm{CCl}_{4}$ - dependent suicidal inactivation of P450. Dalton Trans. 2014; $21: 43(39): 14833-40$.

29. Kobayashi A, Ohta T, Yamamoto M. Unique function of the Nrf2Keap1 pathway in the inducible expression of antioxidant and detoxifying enzymes. Method Enzymol. 2004;378:273-286.

30. Cemek M, Aymelek F, Buyukokuroglu M, Karaca T, Buyukben A, Yilmaz F. Protective potential of royal jelly against carbon tetrachloride induced-toxicity and changes in the serum sialic acid levels. Food Chem Toxicol. 2010;48:2827-2832.

31. Yang Z, Zhang X, Yang L, Pan Q, Li J, Wu Y, Chen M, Cui S, Yu J. Protective effect of Anoectochilus roxburghii polysaccharide against CCl4-induced oxidative liver damage in mice. Inter J Biol Macromol. 2016;30(16):31220.

32. Soto C, Pérez J, García V, Uría E, Vadillo M, Raya L. Effect of silymarin on kidneys of rats suffering from alloxan-induced diabetes mellitus. Phytomedicine. 2010;17:1090-1094. 